\section{Ashes, by Steve McQueen}

Quote: LUERSEN, Paula. Ashes, by Steve McQueen. Porto Arte: Revista de Artes Visuais. Porto Alegre: PPGAV-UFRGS, v. 22, n. 36, p.1-3, jan.jun. 2017. e-ISSN 2179-8001. DOI: http://dx.doi.org/10.22456/2179-8001.80118

Translated by Ana Carolina Azevedo and Bruno Declerque

Abstract: This review covers the experience of visiting Ashes, a video installation by Steve McQueen, exhibited at the Institute of Contemporary Art, in Boston. It explores the expectations, surprises and reflections raised by the work and the way McQueen introduces, through the image, the question of memory.

Keywords: Steve McQueen. Video installation. ICA/Boston. Experience. Memory.

At the door of one of the rooms of the Institute of Contemporary Art in Boston. there was a pile of posters. Papers bringing a narrative on a printed image. A huge pile of posters, as if it claimed to be shared with the greatest number of people passing by. At first, they seemed to display a confusing text full of repeated phrases - a vice of language that indicated the orality of a spoken story. But soon, by continuing to read, the content of the text overlapped the first impressions in the same way the white letters took on the color of the image on the poster. The text narrated the death of a boy who, apparently, had been involved in a drug trafficking scheme. A subject that soon touched me and sounded quite familiar, considering the Brazilian reality I was used to. This type of situation, unfortunately, is daily featured in the newspapers of big cities, which created an expectation on what would be presented there.

The posters were part of a video installation by Steve McQueen, a British artist and filmmaker who - informed the opening text of the exhibition - had met the boy alluded in the narrative during the process of recording a previous work done on the Grenadine Islands, in the Caribbean. In the poster, behind the text, a body had its back to the reader. A slim black figure, facing the sea, on the edge of a canoe. But, what were the first images suggested by reading the text in the posters? Of course, all the sort of things to which the narrated situation usually connects: I imagined cutouts from the place where the situation happened, portraits of the family or of the victim itself - images so often reproduced on pages of newspapers and TV screens to report the loss of another youth to the urban violence, due to the traffic.
But the very way in which the text narrated what happened already presented a fundamental difference in relation to a journalistic approach: it talked about death. Instead of the informational tone, that is characteristic of the media in this type of situation, the narrated story was a testimony: the testimony of someone who seemed directly involved in the situation. And moreover, from a narrator who had witnessed the boy's death:

He said "I'm not going anywhere, if you want to kill me, kill me here in front of everyone, so everyone can see, I'm not going anywhere", and then they shot his hand to make him drop what he was holding. And when they shot his hand, he let it go, but he tried to run and then they shot him in the back, and when he felt it, one of the guys came up on him and shot his belly and legs. ${ }^{1}$

The direct testimony, detailing the boy's posture during the episode, contrasts with the way in which tragedies are usually reported, aimed at statistics and objective information. Still, I hesitated to enter the room: what would be the images that awaited me given the plot that was shown me? Would McQueen's choices be capable of subverting what causes on us tragic event, so often announced and reverberated that no longer seems to affect us, to propose another kind of relationship?

In the dark room, the video accompanied the details of a process of construction: men hammering; the buzz of saws in operation; the focus on materials such as cement and marble. Then, we have a glimpse of the scene - a simple graveyard, in the midst of a green area - and the craft of those workers - the construction of a tomb. The camera focused on the treatment given by the workers to the marble and the gestures that gradually materialized the massive symbol of something that was absent. The construction of the tombstone was then overlapped by the narrative of the poster, which was now sonorous, talking about the death of the boy in the words of who seemed to be a close friend:

He came back from the island and I had come from school in the late afternoon to clean the house. And he came and walked the house in wet clothes, with sand on his feet, and I asked him, 'Can't you see what I'm doing? Can't you see that I'm cleaning and you're walking like this around the house?' And he said, 'I'm rich now, I can do anything I want'. And I turned to him and our friend turned to him and said 'what?'. He turned around and said 'We found something

1. Excerpt from the text on the poster at the door of the Ashes video-installation. 
on the island and we can't spend the money now'. And Kevin turned to him and said, 'Well, just give it back'. We didn't know he had found the drugs. ${ }^{2}$

From the crosses between sound and image emerges the focus on the dust. First, in the thin dust that remains from the marble by inscribing a name on the tombstone. Then, at the insistence of the narrator on the rest of the sand that the boy spread on the floor of the house and that there he found a correlation with the ashes. The images constructed the persistence of the dust, the reference to the ashes - and to all the grief that is in the ashes, the possible final destiny of a body. This occurred in several parts of the video, which accompanied the final assembly of the tomb bearing the boy's name: Ashes. And these images finally led to the contemplation of what remains only as a vestige: what remains of the material waste of a construction process; what remains of a sequence of facts as a narrated history; what is left of life and tries to overcome death with the building of a permanent object.

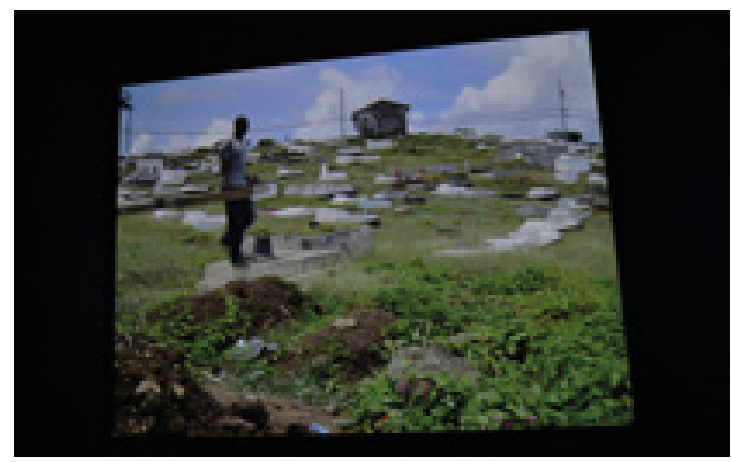

Figure 1. Steve McQueen, Ashes (2017, Institute of Contemporary Art/Boston). Frame of the video installation. Photo by the author.

At one point I saw some people coming from across the room and I noticed their interest in seeing what the screen showed. It was only then that I took a peek at what was on the other side of the screen, on the back of the images that I had been watching. And it was a surprise to see that another video was being presented and to rediscover what was hidden behind the letters on the entrance posters: the boy with his back turned to the spectator, sitting on the edge of a canoe, watching the sea. An image that unfolded in a luminous, spontaneous scene. Extremely beautiful.

2. Excerpt from the text on the poster at the door of Ashes, narrated during the video installation.
It counterposed, in a sense, what had been shown on the other side of the screen. We could now see a boy skillfully sailing a canoe, who sometimes stared at the camera with a wide smile amidst the blue sea. There was an enchantment in that breezy summer atmosphere, made by that of slow sailing through the waves. The video sounded like an unpretentious record of a part of Ashes' daily life, which was revealed by the following narrative, in the same voice, in a loop:

I met Ashes as a friend. All of us were young. We grew up in the same neighborhood. So, we used to live in a ghetto, you know? We all use to swim together. We used to go fishing, we swim, everything. Ashes is a nice guy, a bright guy in the ocean. ${ }^{3}$

And the look of the boy to the camera was so sweet; the landscape that surrounded him, so impressive; that there seemed to be another form of possible permanence, far distant from that inscription in marble, from the weight of mourning as a consequence of a brutal episode. There was a change of air from one side of the screen to the other, altering the record of the episodes and facts narrated about the boy. And then, the very screen projected under its two sides gained that sense of "between", "middle", interposed between representations of life and death, positioned in the transition between images that brought affections in opposite directions.

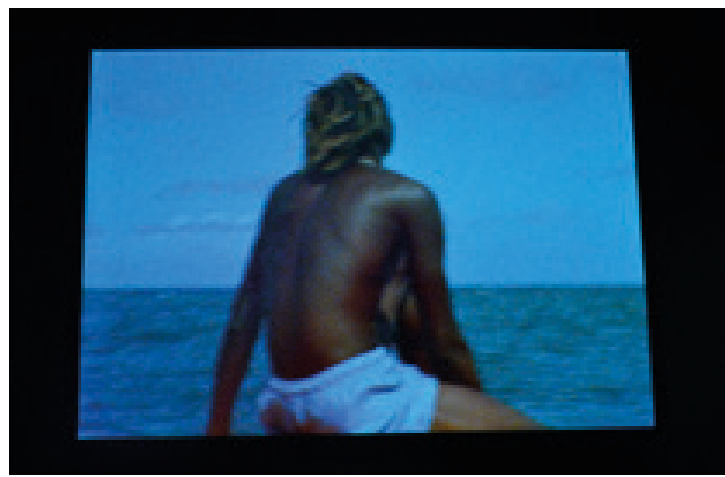

Figure 2. Steve McQueen, Ashes (2017, Institute of Contemporary Art/Boston). Frame of the video installation. Photo by the author.

The screen could be imagined as the medium where so many other images of the art would fit, images that vibrate that transition without solving it. As in Alfredo Jaar's The eyes of Gutete Emerita (1996)4 which instead of images of violence and death, exhibits only the eyes of those who witnessed them as

3. Excerpt from the text on the poster at the door of Ashes, narrated during the video installation.

4. Installation exposed in Brazil during the $29^{\text {th }}$ São Paulo Biennial, in 2010. 
the facts unfold only as narrative; as in the photographs, secretly taken by Henrik Ross (1941-44) in the ghetto of Losz, showing families waiting in line for alleged deportation to labor camps, families who didn't, at the time - much like the photographer -, know that the final destination of the journey would be the concentration camps; as in Alexander Gardner's Portrait of Lewis of Payne (1875) ${ }^{6}$, the portrait of a handcuffed man staring at the camera, in a seemingly banal pose and scenario, were it not for the fact that this was the moment immediately preceding the execution of the man photographed. Images that never cease to balance life and death, the ordinary and the violence, the triviality of records and the fate of images, seeming to have powers that operate in the space of this transition. The difference in these works, however, lies in the fact that Steve McQueen's installation initially opposed the two video sequences as if the thin projection screen could open and harbor the cruel narrative that opposed the vibrating body that sailed the boat and the inert body to be buried in marble tombstone. With the opposition of the two sides of the screen, it seemed to take place, thus, a before and after, a record of life and a record of death.

After some time, however, this duality ceased to be sustained, since the video that showed Ashes maneuvering the boat didn't stop repeating itself, in a loop. And such a scene, when in repetition - always the same -, showed its limited sense of remembrance: it was also a remnant of time, a surplus of what happened, of what could no longer be again. Consequently, by its repetition, it stopped opposing to the construction of the tombstone and started to add itself to it as posthumous exhibition of a scene of the past. Attempts to bend time, to give consistency to a presence that is now absent, to an absence that continued to persist and needed to make an image.

Although so different, though surrounded by atmospheres and ways so disparate to express death and life, the two videos, on opposite sides of the screen, started to affect me by this shared characteristic: the attempt to give body to the one who does not cease to pulsate, even under the aegis of absence, and continues to inscribe to life as a remembrance. In Steve McQueen's words ${ }^{7}$ :

5. Photographs from the Memory Unearthed - Henryk Ross exhibition, exhibited in 2017 at the Museum of Fine Arts, Boston.

6. Photograph present in the book The Emancipated Spectator, by Jacques Rancière, p.165.

7. Comment on the work recorded in the text Steve McQueen's 'Ashes' haunts Institute of Contemporary Art, by Celina Colby.
"Life and death have always been side by side in all aspects of life. Our day-to-day life is full of ghosts". Side by side - or on both sides of the screen - the videos began to vibrate as one: remains of time, records of space that sought to give consistency and make an image of what can no longer be.

\section{EXHIBITION DATA}

Title: Ashes

Artist: Steve McQueen.

Technique: Video installation.

Exhibition review: February $15^{\text {th }}, 2017$, to February $25^{\text {th }}$, 2018. Exhibition organized by Dan Byers, curated by Mannion Family Senior, with curatorial assistant Jeffrey De Blois.

Location: The Institute of Contemporary Art/Boston, in Kim and Jim Pallotta Gallery.

\section{REFERENCES}

BYERS, Dan. Steve McQueen: Ashes. Institute of Contemporary Art: Boston, 2017.

COLBY, Celina. Steve McQueen's 'Ashes' haunts Institute of Contemporary Art. Disponível em: <http://baystatebanner. com/news/2017/feb/24/steve-mcqueens-ashes-hauntsinstitute-contemporary/> Acessado em 24 jun. 2017.

FARIAS, Agnaldo; ANJOS, Moacir (orgs.) Catálogo da $29^{a}$ Bienal de São Paulo: Há sempre um copo de mar para um homem navegar. São Paulo, Fundação Bienal de São Paulo, 2010.

SUTNIK, Maia-Mari (org). Memory Unearthed - The Lodz Ghetto Photographs of Henryk Ross. Ontario: Yale University Press, 2007. RANCIĖRE, Jacques. O Espectador Emancipado. Trad. José M. Justo. Lisboa: Orfeu Negro, 2010.

Paula Luersen: Doctoral student in Art History, Theory and Criticism by the Post-Graduate Program in Visual Arts at the Federal University of Rio Grande do Sul.

Text submitted on 2017. 